\title{
Pengembangan Media KOPER FK (Kotak Persoalan FPB dan KPK) Pada Materi FPB dan KPK untuk Siswa Kelas IV SDN Bendan Ngisor Semarang
}

\author{
Prasetyo Kuncoro \\ Program Studi Pendidikan Guru Sekolah Dasar; FIP Universitas PGRI Semarang; Jl. \\ Sidodadi Timur No 24, Dr. Cipto Semarang 50125 Jawa Tengah; \\ prasetyokuncoro6@gmail.com
}

\begin{abstract}
Abstrak. Penelitian ini diawali dari sebagian besar siswa yang kesulitan dalam memahami materi FPB dan KPK pada mata pelajaran Matematika. Permasalahan tersebut menjadi pertimbangan bagi peneliti untuk melakukan penelitian. Penelitian ini bertujuan untuk mengahasilkan media pembelajaran KOPER FK (Kotak Persoalan FPB dan KPK) dan mengetahui kualitas media pembelajaran KOPER FK (Kotak Persoalan FPB dan KPK). Penelitian ini dilakukan kepada sekelompok siswa kelas V di SD Bendan Ngisor Semarang. Jenis penelitian ini adalah penelitian dan pengembangan yang diadaptasi dari tahapan Sugiyono serta Borg and Gall yang kemudian dimodifikasai antara lain potensi dan masalah, pengumpulan data, desain produk, validasi, uji coba pemakaian, revisi produk, uji coba produk, revisi desain, revisi produk. Hasil dari penelitian ini adalah prototipe pembelajaran Matematika mengenai materi FPB dan KPK. Media pembelajaran KOPER FK (Kotak Persoalan FPB dan KPK) memiliki kualitas sangat baik dilihat dari hasil validasi yang dilakukan oleh ahli IPA dan Montessori. Perolehan skor rerata sebesar 3,85. Uji coba terbatas menunjukian terdapat peningkatan nilai yang diperoleh siswa. Selisih nilai posttest dengan pretest sebesar 40. Dengan demikian, dapat dosimpulkan bahwa media pembelajaran KOPER FK (Kotak Persoalan FPB dan KPK) memiliki kualitas yang sangat baik dan membantu siswa memahami materi FPB dan KPK.
\end{abstract}

Kata Kunci: FPB dan KPK, Media Pembelajaran, KOPER BK.

\begin{abstract}
This study began with most students who had difficulty understanding FPB and KPK material in Mathematics. These problems become a consideration for researchers to conduct research. This study aims to produce FK KOPER learning media (FPB and KPK Problems Box) and find out the quality of FK KOPER learning media (FPB and KPK Problem Boxes). This research was conducted to a group of fifth grade students at Bendan Ngisor Elementary School in Semarang. This type of research is research and development adapted from the Sugiyono and Borg and Gall stages which are then modified including potential and problems, data collection, product design, validation, trial use, product revision, product trial, product revision, product revision. The results of this study are prototypes of Mathematics learning regarding FPB and KPK material. FK KOPER learning media (FPB and KPK Problem Box) has a very good quality seen from the results of validation conducted by science experts and Montessori. Average score of 3.85. Limited trials show there is an increase in students' grades. The difference between the posttest score with the pretest is 40 . Thus, it can be concluded that the FK KOPER learning media (FPB and KPK Problems Box) has very good quality and helps students understand FPB and KPK material.
\end{abstract}

Keywords : FPB and KPK, Learning Media, KOPER BK.

Caruban : Jurnal Ilmiah Pendidikan Dasar 3(2), 107-129, Juli 2020

DOI: http://dx.doi.org/10.33603/.v3i2.3064, p-ISSN 2615-1391, e-ISSN 2620-3219

CProdi PGSD Universitas Swadaya Gunung Jati 


\section{Pendahuluan}

Pendidikan merupakan salah satu sarana dalam mendidik siswa. Melalui pendidikan seseorang dapat belajar sesuatu yang membantu dirinya dalam menjadi orang yang berkualitas dan berkarakter. Dalam proses pendidikan terdapat kegiatan yang membelajarkan siswa. Peraturan pemerintah RI No. 19/2005, Pasal 19 mengatakan bahwa "proses pembelajaran pada satuan pendidikan diselenggarakan secara interaktif, inspiratif, menyenangkan, menantang, memotivasi peserta didik, serta memberikan ruang yang cukup bagi prakarsa, kreativitas, dan kemandirian sesuai dengan bakat, minat, dan perkembangan fisik serta psikologi peserta didik". Dengan adanya peraturan ini diharapkan bahwa proses pendidikan di sekolah bukan lagi sebagai proses pengajaran yang mana guru menjadi pusat informasi melainkan adanya proses pembelajaran dimana siswa yang dominan aktif dalam menggali makna serta menyerap pengetahuan.

Proses pendidikan salah satunya melalui proses pembelajaran yang merupakan suatu proses dan rangkaian suatu usaha guru dalam rangka untuk membuat peserta didik belajar dan menciptakan kondisi agar terjadi kegiatan belajar. Pembelajaran lebih menekankan pada cara-cara untuk mencapai tujuan dan berkaitan dengan cara mengorganisasikan isi pembelajaran, menyampaikan isi pembelajaran, dan mengelola pembelajaran. (Sutikno dalam Komsiyah, 2012:4). Belajar matematika merupakan proses di mana siswa secara aktif mengkonstruksi pengetahuan matematika. Hal ini didukung oleh teori belajar konstruktivisme di mana teori konstruktivis ini menyatakan bahwa siswa harus menemukan sendiri dan mentransformasikan informasi, mengecek informasi baru dengan aturan-aturan lama dan merevisinya apabila aturanaturan itu tidak lagi sesuai. Oleh karena itu, di dalam kelas guru tidak hanya sekedar memberikan pengetahuan kepada siswa tetapi guru harus dapat membuat siswa membangun sendiri pengetahuannya.

Menurut Abraham S Lunchins dan Edith N Luchins (Erman Suherman, 2001), matematika dapat dijawab secara berbeda-beda tergantung pada bilamana pertanyaan itu dijawab, dimana dijawabnya, siapa yang menjawabnya, dan apa sajakah yang dipandang termasuk dalam matematika.

Mustafa (Tri Wijayanti, 2011) menyebutkan bahwa matematika adalah ilmu tentang kuantitas, bentuk, susunan, dan ukuran, yang utama adalah metode dan proses untuk menemukan dengan konsep yang tepat dan lambang yang konsisten, sifat dan hubungan antara jumlah dan ukuran, baik secara 
abstrak, matematika murni atau dalam keterkaitan manfaat pada matematika terapan.

Berdasarkan Elea Tinggih (Erman Suherman, 2001), matematika berarti ilmu pengetahuan yang diperoleh dengan bernalar. Hal ini dimaksudkan bukan berarti ilmu lain diperoleh tidak melalui penalaran, akan tetapi dalam matematika lebih menekankan aktivitas dalam dunia rasio (penalaran), sedangkan dalam ilmu lain lebih menekankan hasil observasi atau eksperiment disamping penalaran.

James dan James (Erman Suherman, 2001), mengatakan bahwa matematika adalah ilmu tentang logika mengenai bentuk, susunan, besaran, konsepkonsep yang berhubungan satu dengan yang lainnya dengan jumlah 13 yang banyak yang terbagi ke dalam tiga bidang, yaitu aljabar, analisis, dan geometri. Namun ada pula kelompok lain yang beranggapan bahwa matematika adalah ilmu yang dikembangkan untuk matematika itu sendiri. Ilmu adalah untuk ilmu, dan matematika adalah ilmu yang dikembangkan untuk kepentingan sendiri. Matematika adalah ilmu tentang struktur yang bersifat deduktif atau aksiomatik, akurat, abstrak, dan ketat. Dengan memperhatikan definisi matematika di atas, maka menurut

Dari definisi-definisi di atas, dapat disimpulkan bahwa matematika merupakan ilmu pengetahuan yang diperoleh dengan bernalar yang menggunakan istilah yang didefinisikan dengan cermat, jelas, dan akurat, epresentasinya dengan lambang-lambang atau simbol dan memiliki arti serta dapat digunakan dalam pemecahan masalah yang berkaitan dengan bilangan.

Menurut Karso (2007: 2.7) tujuan pembelajaran matematika di jenjang pendidikan dasar mengacu kepada fungsi matematika serta kepada tujuan pendidikan nasional yang telah dirumuskan dalam GBHN. Diungkapkan dalam GBHN matematika kurikulum pendidikan dasar, bahwa tujuan umum diberikannya matematika di jenjang pendidikan dasar meliputi dua hal, yaitu: 1) Mempersiapkan siswa agar sanggup menghadapi perubahan keadaan di dalam kehidupan dan di dunia yang sedang berkembang, melalui latihan bertindak atas dasar pemikiran secara logis, kritis, cermat, jujur, dan efektif, 2) Mempersiapkan siswa agar dapat menggunakan matematika dan pola pikir matematika dalam kehidupan sehari-hari, dan dalam mempelajari berbagai ilmu pengetahuan. 
Tujuan umum pembelajaran matematika pada jenjang pendidikan dasar yang pertama di atas memberikan penekanan pada penataan nalar dan pembentukan sikap siswa. Sedangkan pada tujuan yang kedua memberikan penekanan pada keterampilan dalam penerapan matematika, baik dalam kehidupan sehari-hari maupun dalam membantu mempelajari ilmu pengetahuan lainnya. (Karso. 2007: 2.8)

Karso (2007: 2.8) diungkapkan dalam GBPP Matematika SD, bahwa tujuan pengajaran matematika di SD meliputi 4 hal, yaitu: 1) Menumbuhkan dan mengembangkan keterampilan berhitung (menggunakan bilangan) sebagai alat dalam kehidupan sehari-hari, 2) Menumbuhkan kemampuan siswa yang dapat dialihgunakan melalui kegiatan matematika, 3) Memiliki pengetahuan dasar matematika sebagai bekal belajar lebih lanjut di Sekolah Lanjutan Tingkat Pertama (SLTP), 4) Membentuk sikap logis, kritis, cermat, kreatif, dan disiplin.

Berdasarkan penjelasan di atas dapat disimpulkan bahwa tujuan dari pembelajaran matematika itu sendiri adalah membekali peserta didik agar mampu terjun ke masyarakat yang dibekali dengan ilmu-ilmu yang bersifat logis. Setelah siswa diberi pembelajaran matematika yang bersifat logis diharapakan siswa mampu membentuk sikap yang logis, kritis, cermat, kreatif, dan disiplin. Serta diharapkan siswa mampu menerapkan matematika dalam kehidupan sehari-hari.

Guru sebagai pendidik tentu telah berupaya dengan menerapkan metode pembelajaran, model pembelajaran maupun media pembelajaran yang sekiranya memberikan keefektifan serta keefesien guna menunjang tercapainya tujuan pembelajaran Matematika tersebut. Tujuan yang telah ditetapkan harus mengacu pada kompetensi dasar, dengan demikian guru hendaknya berupaya untuk menerapkan pembelajaran yang dapat memenuhi kompetensi dasar yang harus dimiliki siswa. Dengan demikian, guru diharapkan dapat memahami dan menerapkan beberapa faktor yang mempengaruhi tercapainya tujuan pembelajaran di antaranya, kreatifitas guru, karakteristik siswa, lingkungan tempat sosial, metode atau teknik dalam mengajar serta media pembelajaran. Guru juga dituntut dalam menyiapkan pembelajaran yang dapat menarik perhatian siswa, mempersiapkan penyampaian informasi atau materi pembelajaran yang mudah serta media pembelajaran digunakan untuk menyampaikan informasi atau materi pelajaran tersebut. Hal ini sesuai dengan pendapat Kustandi dan Sutjipto (2011: 9), bahwa media pembelajaran adalah alat yang dapat membantu proses belajar mengajar dan berfungsi untuk memperjelas 
makna pesan yang disampaikan, sehingga dapat mencapai tujuan pembelajaran dengan lebih baik dan sempurna. Penggunaan media sangat diperlukan untuk memudahkan penyerapan materi bagi siswa SD sesuai standar kompetensi kelulusan yang merupakan kualifikasi kemampuan kelulusan yang mencakup sikap, pengetahuan, dan keterampilan sebagaimana yang telah ditetapkan dalam standar proses kurikulum 2013.

Faktor-faktor yang mempengaruhi tercapainya tujuan pembelajaran di antaranya, guru, siswa, lingkungan, metode atau teknik serta media pembelajaran. Media pembelajaran menjadi bagian penting yang harus mendapat perhatian dari guru. Media pembelajaran digunakan untuk menyampaikan informasi atau materi pelajaran. Menurut Sadiman (1993) dalam Kustandi dan Sutjipto (2011: 7), media adalah perantara atau pengantar pesan dari pengirim ke penerima pesan.

Pada saat proses pembelajaran guru dituntut untuk memperhatikan strategi belajar mengajar sehingga menciptakan suasana yang aktif, efektif dan menyenangkan. Dalam proses pembelajaran, bahasa merupakan penunjang keberhasilan dalam semua mata pelajaran. Tetapi kenyatannya keterampilan berbahasa anak masih jauh dengan apa yang diharapkan. Padahal melalui pembelajaran yang dilakukan di dalam kelas anatara guru dengan siswa banyak melakukan komunikasi. Saat ini guru tidak hanya mengatur strategi seperti yang telah dijelaskan sebelumnya. Namun, guru juga dituntut untuk dapat berfikir kreatif dan inovatif pada saat proses pembelajaran. Hal ini dikarenakan agar siswa tidak merasa bosan dan jenuh pada saat guru menyampaikan materi. Keberhasilan pada saat proses pembelajaran banyak dipengaruhi faktor. Faktor-faktor diantaranya proses penyampaian materi guru kepada siswa. Sebagaian besar siswa kurang memahami materi karena penyajian gurunya tidak menyenangkan. Karena hal tersebut, maka hasil belajar siswa juga akan menurun.

Media pembelajaran merupakan salah satu komponen pembelajaran yang mempunyai peranan penting dalam proses pembelajaran. Pemanfaatan media seharusnya merupakan bagian yang harus mendapat perhatian guru sebagai fasilitator dalam kegiatan pembelajaran. Oleh karena itu setiap pendidik perlu mempelajari bagaiamana menetapkan media pembelajaran dalam proses belajar mengajar. Selain menggunakan media, pendidik juga harus mengetahui bagaiamana cara mengelola pembelajaran yang berlangsung setiap proses pembelajaran. Salah satu cara agar guru dapat melakukan proses pembelajaran dengan baik adalah mengetahui karakteristik materi dari mata pelajaran yang akan diajarkan kepadanya. 
Berdasarkan hasil wawancara dan informasi dari guru kelas IV SD Negeri Bendan Ngisor Semarang yaitu ibu Triyani, S.Pd, pada saat proses pembelajaran penggunaan media pembelajaran untuk materi FPB dan KPK di kelas IV masih jarang digunakan. Beliau mengatakan minimnya penggunaan media pembelajaran diakibatkan karena guru masih sulit menemukan media yang cocok untuk mengatasi masalah yang dihadapi siswa serta memiliki keterbatasan waktu untuk membuat media pembelajaran yang konvensional. Beliau juga mengatakan bahwa siswa juga kesulitan dalam memahami soal cerita terkait dengan materi FPB danKPK. Pada proses pembelajaran media pembelajaran yang digunakan kurang mendukung pembelajaran karena guru hanya menggunakan media papan tulis diam sehingga siswa kurang paham dan mengerti. Selain itu diperoleh data bahwa, sikap siswa kelas IV dalam proses pembelajaran kurang disiplin terbukti ketika proses pembelajaran sedang berlangsung terdapat beberapa siswa yang masih sibuk dengan kegiatanya sendiri. Siswa tidak memperhatikan penjelasan guru. Semangat siswa dalam proses pembelajaran juga kurang, hal ini terbukti dari banyaknya siswa yang acuh dalam proses pembelajaran. Salah satu strategi yang dapat digunakan adalah dengan menggunakan media pembelajaran yang mendukung materi pembelajaran dengan kesesuaian karakteristik siswa. Penggunaan media pembelajaran dalam proses pembelajaran diharapkan dapat memacu siswa untuk lebih aktif dalam pembelajaran dan hasil belajar siswa menjadi lebih aktif.

Pada usia Sekolah Dasar yaitu usia antara 5-12 tahun biasanya siswa lebih banyak mengetahui pada hal-hal baru yang dialaminya serta mampu menarik perhatiannya. Pada usia tersebut siswa akan dilatih untuk berfikir secara kristis dan objektif atau terdapat objeknya serta lebih kearah rasional atau masuk akal dalam mengambil sebuah keputusan, karena siswa merasakan secara sendirinya dalam melakukan pengamatan atau pengalaman dalam proses pembelajaran. Dengan kata lain dapat dikatakan bahwa pada usia yang demikian, siswa akan termotivasi dalam proses pembelajaran dimana hal itu didapatkan dari peran guru yang menampilkan proses pembelajaran yang inovatif dan efektif dengan bantuan media pembelajaran.

Berdasarkan permasalah yang ada maka perlu adanya penelitian berkaitan dengan media pembelajaran yang sesuai dengan karakteristik siswa untuk meningkatkan minat belajar siswa pada mata pelajaran Matematika materi FPB dan KPK dan perlu adanya media pembelajaran yang dapat 
menumbuhkan minat siswa agar antusias dalam menjalani proses pembelajaran. Salah satu cara untuk meningkatkan minat dan prestasi belajar siswa adalah menggunakan media pembelajaran dan siswa akan terlibat secara langsung dalam proses pembelajaran dengan adanya media pembelajaran.

Media pembelajaran KOPER FK (Kotak Persoalan FPB dan KPK) adalah media pembelajaran yang berbentuk koper kotak dan di dalamnya terdapat kotak-kotak kecil yang akan di gunakan untuk mengisi kartu angka dan kartu angka tersebut berfungsi untuk menetukan jumlah angka yang akan di cari FPB dan KPK dari angka tersebut,mulai dari puluhan, ratusan dan ribuan. Pada media pembelajaran KOPER FK (Kotak Persoalan FPB dan KPK) akan lebih menekankan pada tahap demonstrasi penyelesaian masalah FPB dan KPK dan melibatkan siswa dalam proses tersebut agar siswa dapat mengetahui dan paham dengan materi FPB dan KPK.

Berdasarkan uraian latar belakang yang telah dijabarkan, maka penulis perlu melakukan pengembangan produk media pembelajaran dengan judul "Pengembangan Media KOPER FK (Kotak Persoalan FPB dan KPK) Pada Materi FPB dan KPK untuk Siswa Kelas IV SDN Bendan Ngisor Semarang."

\section{Metode Penelitian}

Penelitian ini termasuk jenis Penelitian dan Pengembangan (Reseach and Devolpment) yang merupakan metode penelitian secara sengaja, sistematis, bertujuan/ diarahkan untuk mencaritemukan, merumuskan, memperbaiki, mengembangkan, menghasilkan, menguji keefektifan produk, model, metode/ strategi/ cara, jasa, prosedur tertentu yang lebih unggul, baru, efektif, efisien, produktif, dan bermakna. (Putra, 2015: 67)

Menurut Sugiyono (2014:408), penelitian dan pengembangn (Research and Development) berfungsi untuk memvalidasi dan mengembangkan produk. Memvalidasi produk berarti produk tersebut telah ada dan peneliti hanya menguji efektivitas dan validitas produk tersebut. Mengembangkan produk dalam arti luas dapat memperbarui produk yang telah ada (sehingga menjadi lebih praktis, efektif, dan efisien) atau menciptakan produk baru (yang sebelumnya belum pernah ada).

Penelitian dan pengembangan (Reseach and Development) ini dilakukan dalam proses untuk menghasilkan sebuah produk baru. Model penelitian dan Pengembangan ini mengacu pada tahapan Reseach and Deveopment (R\&D)

Caruban : Jurnal Ilmiah Pendidikan Dasar 3(2), 107-129, Juli 2020

DOI: http://dx.doi.org/10.33603/.v3i2.3064, p-ISSN 2615-1391, e-ISSN 2620-3219

CProdi PGSD Universitas Swadaya Gunung Jati 
yang dikemukakan oleh Borg and Gall yang terdapat dalam Sugiyono (2010:409), langkah-langkah tersebut yaitu 1) potensi dan masalah, 2) pengumpulan data, 3) desain produk 4) validasi, 5) uji coba pemakaian, 6) revisi produk, 7) uji coba produk, 8) revisi desain, 9) revisi produk 10) produksi masal.

Prosedur pengembangan media KOPER FK disesuaikan dengan langkah tersebut, namun dibatasi hingga pada tahap revisi produk tahap akhir karena penelitian ini hanya sampai menguji kelayakan produk bukan untuk produksi masal. Tahapan tersebut dapat digambarkan dalam bagan berikut:

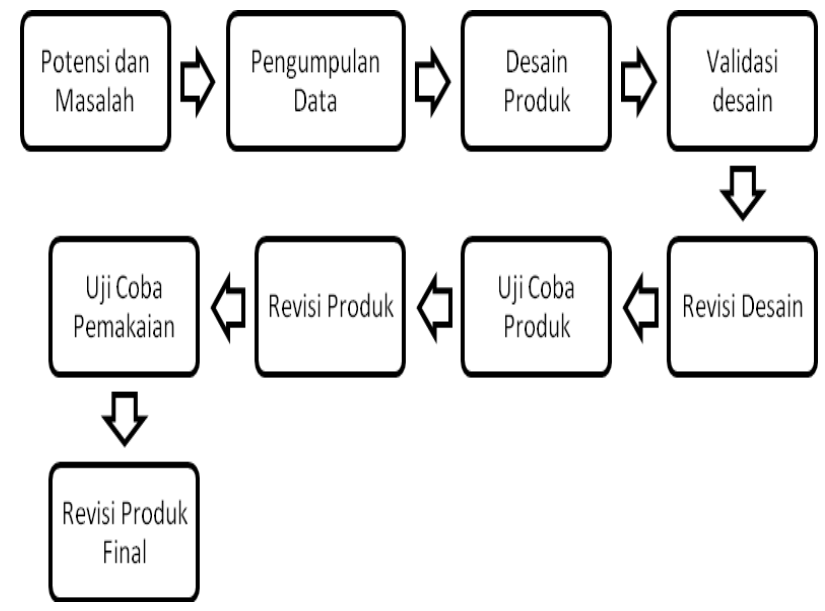

Bagan 1. Tahapan Pengembangan Menurut Borg \& Gall

Adapun Langkah-langkah prosedur penelitian dan pengembangam metode Reseach and Development (R\&D) dapat dijelaskan sebagai berikut.

Penelitian ini berangkat dari adanya suatu potensi atau masalah. Potensi adalah sesuatu yang bila didayagunakan memiliki nilai tambah yang lebih. Sedangkan masalah adalah suatu penyimpangan antara yang diharapkan dengan apa yang terjadi. Potensi dan masalah dalam penelitian ini didapatkan dengan cara melakukan observasi dan wawancara. Berdasarkan hasil observasi dan wawancara pada tanggal 26 Agustus 2019 dengan guru kelas IV SDN Bendan Ngisor Semarang yaitu dengan ibu Triyani, S.Pd dapat diketahui bahwa sebagian besar siswa kesulitan dalam memahami materi pelajaran Matematika terutama materi FPB dan KPK pada BAB 1 tentang pecahan di pelajaran 2 yaitu tentang FPB dan KPK. Guru sudah menyampaikan materi pembelajaran dengan baik, namun tingkat keaktifan siswa juga masih rendah, siswa kurang antusias dalam kegiatan belajar mengajar yang sedang berlangsung serta media pembelajaran yang belum mendukung proses pembelajaran berlangsung karena hanya menggunakan media papan tulis. 
Langkah selanjutnya yang harus dilakukan oleh peneliti adalah membuat rancangan desain dari produk yang akan dikembangkan. Desain produk media pembelajaran KOPER FK disesuaikan dengan materi dari Kompetensi Dasar yaitu tentang Faktor Persekutuan Terbesar (FPB) dan Kelipatan Persekutuan Terkecil (KPK) serta berkaitan dengan permasalahan FPB dan. Setelah membuat rancangan desain produk yang dikembangkan, peneliti melakukan validasi desain yang bertujuan untuk memberikan penilaian berdasarkan penilaian rasional tanpa melakukan uji coba di lapangan. Validasi desain dilakukan oleh validator yaitu ahli materi dan ahli media berupa angket. Setelah desain produk divalidasi oleh para ahli, maka peneliti melakukan revisi terhadap desain media pembelajaran KOPER FK berdasarkan masukan berupa kritik dan saran dari para ahli. Produk awal yang sudah direvisi dan divalidasi oleh ahli materi dan ahli media (draft II) kemudian diuji cobakan dalam skala terbatas. Uji coba ini dilakukan pada subjek lain diluar subjek penelitian sebanyak 6 siswa. Setelah melakukan revisi, tahap selanjutnya yang dilakukan adalah produk tersebut (draft III) diujicobakan dalam skala lebih luas dengan subyek penelitian sejumlah 40 siswa.

Jenis data yang digunakan dalam penelitian ini adalah data kuantitatif. Hasil data yang diperoleh dari tanggapan siswa mengenai penggunaan media pada tahap uji coba pemakaian dan hasil kegiatan pre-test dan post-test akan dianalisis menggubakan metode statistik inferensial.

Teknik analisis data yang digunakan dalam penelitian ini yaitu,

1. Analisis data hasil validasi dari ahli materi dan ahli media:

$$
\begin{gathered}
f \\
P=-
\end{gathered} \bar{N} 100 \%
$$

Keterangan :

$P=$ Persentase validitas

$F=$ Jumlah skor hasil pengumpulan data

$N=$ Skor maksimal

Tabel 1. Persentase Kriteria Validitas

\begin{tabular}{cc}
\hline Presentase & Kriteria \\
\hline $0 \%-20 \%$ & Tidak valid \\
$21 \%-40 \%$ & Kurang valid \\
$41 \%-60 \%$ & Cukup valid \\
$61 \%-80 \%$ & Valid \\
$81 \%-100 \%$ & Sangat valid \\
\hline
\end{tabular}


2. Analisis data hasil observasi kegiatan pembelajaran, dengan rumus :

$$
\begin{gathered}
f \\
P=-x 100 \% \\
N
\end{gathered}
$$

Keterangan :

$P=$ Persentase validitas

$F=$ Jumlah skor hasil pengumpulan data

$N=$ Skor maksimal

3. Analisis data hasil tanggapan siswa

$$
P=-x 100 \%
$$

Keterangan :

$P=$ Persentase validitas

$F=$ Jumlah skor hasil pengumpulan data

$N=$ Skor maksimal

Tabel 2. Persentase Hasil Tanggapan Siswa

\begin{tabular}{cc}
\hline Presentase & Responden \\
\hline $81 \%-100 \%$ & Sangat Baik \\
$61 \%-80 \%$ & Baik \\
$41 \%-60 \%$ & Cukup Baik \\
$21 \%-40 \%$ & Kurang Baik \\
$0 \%-21 \%$ & Sangat Tidak Baik \\
\hline
\end{tabular}

Adapun indikator keberhasilan dalam penelitian yaitu, (1) Media pembelajaran KOPER FK dikatakan valid apabila persentase kriteria validitas media pembelajaran rata-rata $\geq 80 \%$ (Valid). (2) Media pembelajaran KOPER FK dikatakan praktis apabila persentase kriteria ketercapaian pembelajaran dan persentase tanggapan hasil tanggapan siswa rata-rata $\geq 80 \%$ (Sangat Baik) (3) Media pembelajaran KOPER FK (Kotak Persoalan FPB dan KPK) dikatakan efektif dalam meningkatkan pemahaman konsep Matematika apabila hasil belajar siswa setelah menggunakan media KOPER FK (Kotak Persoalan FPB dan KPK) mengalami peningkatan pemahaman secara signifikan dibandingkan sebelum menggunakan media pembelajaran KOPER FK (Kotak Persoalan FPB dan KPK).

\section{Hasil dan Pembahasan}

Hasil penelitian "Pengembangan Media KOPER FK (Kotak Persoalan FPB dan KPK) Pada Materi Matematika Siswa Kelas IV SDN Bendan Ngisor Semarang" telah dilaksanakan sesuai dengan tahapan Reseach and Development (R\&D) menurut Sugiyono (2015:409) yang telah dimodifikasi. 
Hasil dari penelitian ini berupa media pembelajaran KOPER FK (Kotak Persoalan FPB dan KPK) materi pencernaan makanan hewan ruminansia.

1. Tahapan Pengembangan Media Pembelajaran KOPER FK (Kotak Persoalan FPB dan KPK)

Pada tahap ini dilakukan observasi langsung di SDN Bendan Ngisor Semarang untuk mendapatkan potensi dan masalah yang ada. Berdasarkan hasil observasi dan wawancara pada tanggal 26 Agustus 2019 dengan guru kelas IV SDN Bendan Ngisor Semarang dapat diketahui bahwa sebagian besar siswa kesulitan dalam memahami materi pelajaran Matematika terutama materi FPB dan KPK.

Pengumpulan data/informasi sebagai bahan untuk mempersiapkan pengembangan media pembelajaran dengan melakukan observasi kegiatan pembelajaran dan fasilitas di SDN Bendan Ngisor Semarang. Pengumpulan data memperoleh hasil sebagai berikut.

Tabel 3. Hasil Data Observasi

\begin{tabular}{lll}
\hline Indikator & Pernyataan & Keterangan \\
\hline & $\begin{array}{l}\text { Menggunakan } \\
\text { metode pembelajaran }\end{array}$ & $\begin{array}{l}\text { Menggunakan metode ceramah } \\
\text { dalam pembelajaran. }\end{array}$ \\
& yang inovatif & \\
& Kedalaman materi & Kedalaman materi sudah sesuai \\
& yang disampaikan & dengan tujuan pembelajaran. \\
Kegiatan & sesuai dengan tujuan & \\
Pembelajaran & pembelajaran & \\
& Media pembelajaran & Sudah sesuai dengan materi, \\
& yang digunakan tetapi yang digunakan hanya \\
& sesuai dengan materi & media papan tulis. \\
& Media yang & Kurang menarik karena hanya \\
& digunakan menarik & menggunakan papan tulis saja \\
\hline
\end{tabular}

Setelah tahap pengumpulan data selesai, maka tahap selanjutnya adalah desain produk. Setelah membuat rancangan desain produk yang dikembangkan, peneliti melakukan validasi desain yang bertujuan untuk memberikan penilaian berdasarkan penilaian rasional kepada ahli materi dan ahli media tanpa melakukan uji coba di lapangan.

Berikut merupakan saran dari ahli materi

Caruban : Jurnal Ilmiah Pendidikan Dasar 3(2), 107-129, Juli 2020

DOI: http://dx.doi.org/10.33603/.v3i2.3064, p-ISSN 2615-1391, e-ISSN 2620-3219

CProdi PGSD Universitas Swadaya Gunung Jati 
a. Proses demonstrasi persoalan FPB dan KPK belum begitu terlihat jelas.

b. Pada bagian penjelasan materi menggunakan media harus di jelaskan secara runtut dan perlahan.

c. Perlu perbaikan dalam demonstrasi penyelesaian persoalan FPB dan KPK.

Sedangkan oleh ahli media hanya mendapatkan sedikit saran karena menurut menurut ahli media ini sudah sangat bagus dan hanya perlu revisi sedikit, diantaranya adalah sebagai berikut:

a. Perbaikan pada bagian kartu serta hurufnya agar siswa yang duduk di bagian belakang bisa melihat dengan jelas.

b. Perbaiki juga kopernya jadi lebih besar sehinggamuat untuk pemasangan kartu.

Pada uji coba produk skala terbatas data hasil tes siswa dalam penggunaan media pembelajaran KOPER FK melalui pretest dan posttest adalah sebagai berikut:

Tabel 4. Hasil Belajar Skala Terbatas

\begin{tabular}{ccccc}
\hline No & Nama Siswa & L/P & Nilai Pretest & Nilai Posttest \\
\hline 1 & Adib & L & 40 & 70 \\
2 & Budi & L & 50 & 80 \\
3 & Desy & P & 70 & 90 \\
4 & Fitri & P & 40 & 70 \\
5 & Fanny & P & 60 & 90 \\
6 & Edo & L & 50 & 80 \\
& Nilai Terendah & & 40 & 70 \\
& Nilai Tertinggi & & 70 & 90 \\
& Nilai rata-rata & & 51.6 & 80 \\
\hline
\end{tabular}

Tahap uji coba produk ini juga dilakukan dengan melihat tanggapan siswa. Berikut data hasil angket yang diberikan kepada 6 siswa yang telah melakukan uji coba produk. persentase kepraktisan dari hasil ui coba produk skala terbatas sebesar $93,67 \%$.

Setelah dilakukan uji coba kelompok kecil dan tidak ditemukan adanya kelemahan media atau hambatan, maka peneliti melanjutkan pada tahap selanjtunya yaitu uji coba pemakaian skala luas. Dilakukan pada seluruh subjek penelitian yaitu kelas IV SDN Bendan Ngisor Semarang yang berjumlah 40 siswa. persentase pada tanggapan siswa memperoleh skor 
93,3\%. Berikut dalah hasil tanggapan siswa pada uji coba pemakaian skala luas.

Tabel 5. Hasil Belajar Skala Luas

\begin{tabular}{|c|c|c|c|}
\hline \multirow[t]{2}{*}{ Pertanyaan } & \multicolumn{2}{|c|}{ Respon } & \multirow[t]{2}{*}{ Total } \\
\hline & Ya & Tidak & \\
\hline $\begin{array}{l}\text { Apakah media KOPER FK yang } \\
\text { ditampilkan dalam proses pembelajaran } \\
\text { menarik? }\end{array}$ & 37 & 3 & 40 \\
\hline $\begin{array}{l}\text { Apakah media KOPER FK yang } \\
\text { ditampilkan dalam proses pembelajaran } \\
\text { membantu dalam belajar? }\end{array}$ & 40 & 0 & 40 \\
\hline $\begin{array}{l}\text { Apakah media KOPER FK yang } \\
\text { ditampilkan dalam proses pembelajaran } \\
\text { terlihat jelas? }\end{array}$ & 35 & 5 & 40 \\
\hline $\begin{array}{l}\text { Apakah materi FPB dan KPK dalam } \\
\text { media KOPER FK mudah dipahami? }\end{array}$ & 38 & 2 & 40 \\
\hline $\begin{array}{l}\text { Apakah media KOPER FK materi FPB } \\
\text { dan KPK bermanfaat sebagai } \\
\text { pembelajaran Matematika? }\end{array}$ & 39 & 1 & 40 \\
\hline $\begin{array}{l}\text { Apakah media KOPER FK ini dapat } \\
\text { memotivasi kamu untuk belajar? }\end{array}$ & 38 & 2 & 40 \\
\hline $\begin{array}{l}\text { Apakah kamu senang belajar dengan } \\
\text { menggunakan media pebelajaran KOPER } \\
\text { FK? }\end{array}$ & 39 & 1 & 40 \\
\hline Jumlah & 305 & 15 & 320 \\
\hline
\end{tabular}

Persentase kepraktisan dari hasil tanggapan siswa:

$\mathrm{P}=\mathrm{f}: \mathrm{N} \times 100 \%$

$\mathrm{P}=305 \times 100=30,500$

$\mathrm{P}=30,500: 320=95,3 \%$

$\mathrm{P}=95,3 \%$

Berdasarkan data hasil analisis tersebut menunjukkan bahwa media pembelajaran KOPER FK materi pencernaan makanan hewan ruminansia termasuk kategori sangat baik. 
2. Hasil Kelayakan Media Pembelajaran KOPER FK yang Valid, Praktis, dan Efektif

a. Hasil Kevalidan Media Pembelajaran KOPER FK

Untuk mengetahui kevalidan media pembelajaran SPASI, maka peneliti melakukan tahapan validasi kepada para ahli dengan melihat aspek media dan materi. Berdasarkan validasi ahli media dan ahli materi dapat diperoleh hasil mengenai media pembelajaran KOPER FK pada materi FPB dan KPK. Berikut adalah hasil uji validasi ahli materi dan ahli media pembelajaran KOPER FK.

Tabel 6. Hasil Kevalidan dari Para Ahli

\begin{tabular}{clccc}
\hline Aspek & \multicolumn{1}{c}{ Dosen Ahli } & Hasil & $\begin{array}{c}\text { Presen } \\
\text { tase }\end{array}$ & Keterangan \\
\hline Media & Rofian, S.Pd., M.Pd. & 64 & $95,33 \%$ & Sangat Valid \\
Materi & Ryky Mandarsari, M.Pd. & 57 & $89,23 \%$ & Sangat Valid \\
\hline
\end{tabular}

Berdasarkan hasil persentase validitas pada tabel yaitu 95,33\% \% untuk ahli media menunjukkan bahwa hasil media pembelajaran KOPER FK termasuk kategori "sangat valid" dan 89,23\% untuk ahli materi menunjukkan materi dalam media pembelajaran KOPER FK termasuk kategori "sangat valid". Hasil persentase mengenai hasil uji validasi media pembelajaran KOPER FK materi FPB dan KPK telah melakukan validasi dapat dilihat dalam bentuk diagram berikut.

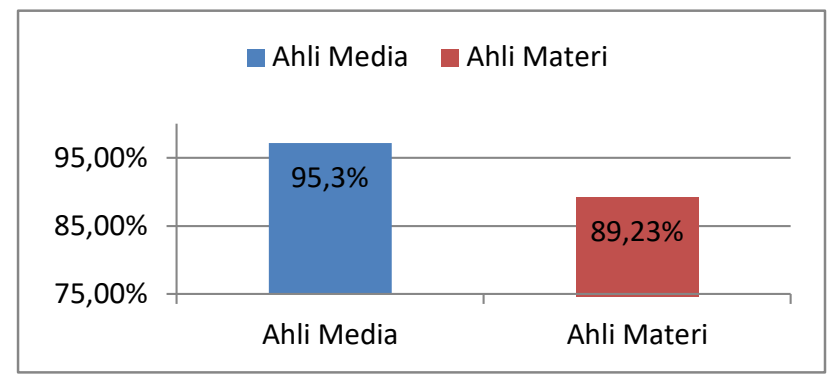

Diagram 1. Hasil Validitas Media pembelajaran KOPER FK

\section{b. Hasil Kepraktisan Media Pembelajaran KOPER FK}

Untuk mengetahui kepraktisan dalam penggunaan media pembelajaran KOPER FK pada materi FPB dan KPK dapat diperoleh dengan dua cara yaitu observasi pelaksanaan pembelajaran dan angket siswa. Berikut data hasil observasi pelaksanaan pembelajaran dan angket siswa pada uji coba pemakaian skala luas yang dapat dilihat pada tabel berikut ini. 
Tabel 7. Hasil Penilaian Observasi dan Angket siswa

\begin{tabular}{cccc}
\hline & \multicolumn{2}{c}{ Observasi Pelaksanaan } & Angket Siswa \\
& O1 & O2 & \\
\hline Skor Total & 89 & 86 & 233 \\
Presentase & $89 \%$ & $86 \%$ & $93,20 \%$ \\
Kriteria & Sangat Baik & Sangat Baik & Sangat Baik \\
Rata-rata & & & \\
Kepraktisan & \multicolumn{3}{c}{$89.4 \%$} \\
Kriteria & \multicolumn{3}{c}{ Sangat Baik } \\
\hline
\end{tabular}

\section{c. Efektivitas Media Pembelajaran KOPER FK}

Untuk mengetahui keefektifan penggunaan media pembelajaran KOPER FK materi FPB dan KPK dapat ditinjau dari hasil belajar siswa. Media pembelajaran KOPER FK materi FPB dan KPK dikatakan efektif apabila tes hasil belajar siswa mengalami peningkatan secara signifikan setelah menggunakan media pembelajaran KOPER FK.

Tes hasil belajar siswa berupa tes kognitif sebanyak 20 soal pilihan ganda dan 10 soal uraian yang diberikan kepada setiap siswa sebagai pretest dan posttest. Tes ini diberikan dalam uji coba produk (skala terbatas) dan uji coba pemakaian (Skala luas). uji coba produk terdiri dari 6 siswa yang diambil secara acak, dan uji coba pemakaian seluruh siswa kelas IV SDN Bendan Ngisor Semarang. Hasil rata-rata nilai siswa setelah menggunakan media pembelajaran KOPER FK adalah 80.

Setelah dilakukan uji coba produk (skala terbatas) dan tidak ditemukan adanya kelemahan media atau hambatan, maka peneliti melanjutkan tahap selanjutnya yaitu uji coba pemakaian (Skala luas). Media pembelajaran KOPER FK yang dikembangkan sudah layak digunakan dan dapat digunakan sebagai alternatif untuk meningkatkan pemahaman konsep siswa. Adanya peningktan hasil belajar siswa dilihat dari hasil pretest dan postest siwa. Rata-rata nilai pretest siswa adalah 51,6 sedangkan untuk rata-rata postest adalah 80 . Sehingga dapat disimpulkan bahwa hasil belajar siswa mengalami peningkatan secara signifikan setelah menggunakan media pembelajaran KOPER FK materi FPB dan KPK dibandingkan dengan sebelum menggunakan media. Hasil pretest dan posttest pada uji coba skala luas dapat digambarkan pada diagram berikut. 


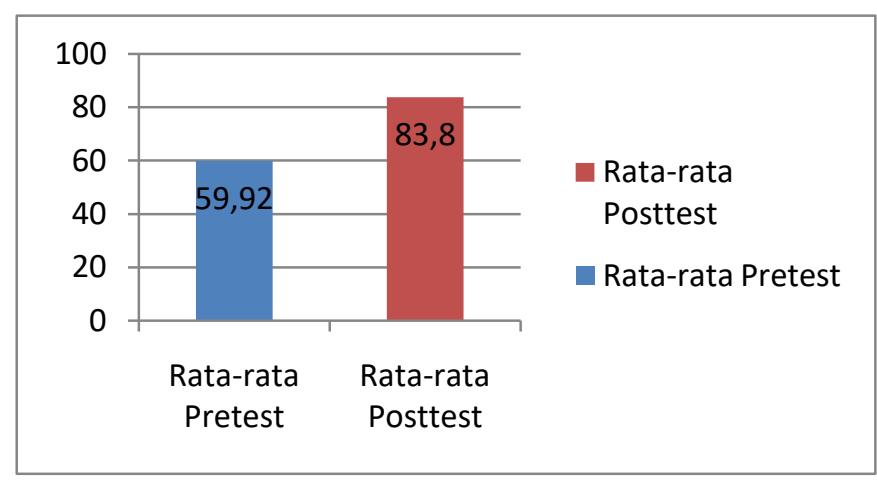

Digram 2. Hasil Keefektifan Produk

Penelitian dan pengembangan (Reseach and Development) ini dilakukan dalam proses untuk menghasilkan sebuah produk baru. Model penelitian dan Pengembangan ini mengacu pada tahapan Reseach and Deveopment (R\&D) yang dikemukakan oleh Borg and Gall yang terdapat dalam Sugiyono (2010:409). Langkah-langkah penelitian dan pengembangan dimulai dari: (1) potensi dan masalah; (2) pengumpulan data; (desain produk; (4) validasi desain; (5) revisi desain; (6) uji coba produk skala terbatas; (7) revisi produk; (8) uji coba pemakaian skala luas; (9) produk akhir. Prosedur pengembangan media KOPER FK disesuaikan dengan langkah Borg and Gall namun dibatasi hingga pada tahap revisi produk akhir karena penelitian ini hanya sampai menguji kelayakan produk media pembelajaran KOPER FK bukan untuk produksi masal. Penelitian ini menghasilkan media pembelajaran KOPER FK materi FPB dan KPK dengan memvisualisasi simulasi dengan demonstrasi yang membuat objek atau media yang berupa sapi bergerak dalam konteks proses pencernaan makanan atau tetap kelihatan seolah-olah hidup sehingga lebih menarik dan memudahkan siswa untuk memahami khususnya pada materi pencernaan makanan hewan ruminansia karena pada materi ini banyak di dominasi dengan materi hafalan. Media pembelajaran KOPER FK ini berperan penting dalam pembelajaran khususnya pelajaran Matematika untuk mengubah pemikiran siswa yang sebelumnya abstrak atau khayal menjadi konkret atau nyata dan mudah dipahami oleh siswa.

Berdasarkan hasil dan analisis data penelitian pengembangan media pembelajaran KOPER FK materi FPB dan KPK, penilaian media pembelajaran KOPER FK dari segi validitas, kepraktisan, dan keefektifan dapat dijelaskan secara rinci sebagai berikut. 


\section{Kevalidan Media Pembelajaran KOPER FK}

Pertama peneliti melakukan validasi media pembelajaran KOPER FK kepada ahli materi. Menurut Niveen dalam Subekti (2010: 76), kevalidan suatu produk dikaitkan dengan dua hal, yaitu apakah hasil dari pengembangan didasarkan pada rasional teoritis yang kuat dan apakah terdapat konsistensi secara internal. Oleh karena itu, setelah peneliti melakukan proses perancangan desain, penyusunan materi dan pembuatan produk awal media pembelajaaran KOPER FK materi pencernaan makanan hewan ruminansia, langkah selanjutnya peneliti melakukan validasi kepada para ahli baik dari ahli materi maupun ahli media. Desain produk yang akan divalidasi didiskusikan dahulu bersama dosen pembimbing. Setelah berdiskusi, dosen pembimbing memberikan pengantar agar rangkuman materi di diskusikan kepada ahli materi. Materi pada media pembelajaran KOPER FK memiliki beberapa aspek yang harus divalidasi, yaitu: kesesuaian materi dengan indikator dan tujuan, indikator dan tujuan pembelajaran, dan kelengkapan materi. Pada saat validasi materi, media pembelajaran KOPER FK mendapatkan revisi atau kritik dan saran dari validator ahli materi, yaitu proses demonstrasi persoalan FPB dan KPK belum begitu terlihat jelas, pada bagian penjelasan materi menggunakan media harus di jelaskan secara runtut dan perlahan, perlu perbaikan dalam demonstrasi penyelesaian persoalan FPB dan KPK.

Setelah validasi ke ahli materi dilanjutkan validasi oleh ahli media. Desain produk media didiskusikan terlebih dahulu bersama dosen pembimbing. Setelah berdiskusi, dosen pembimbing memberikan pengantar agar desain produk media pembelajaran KOPER FK dikonsultasikan kepada dosen ahli media. Desain pada media pembelajaran KOPER FK memiliki beberapa aspek yang harus divalidasi, yaitu: Perbaikan pada bagian kartu serta hurufnya agar siswa yang duduk di bagian belakang bisa melihat dengan jelas, perbaiki juga kopernya jadi lebih besar sehinggamuat untuk pemasangan kartu.. Pada saat validasi desain media pembelajaran berbasis macromedia flash mendapatkan revisi atau kritik dan saran dari bapak validator ahli media. Mengenai hasil validasi media pembelajaran KOPER FK oleh ahli materi yaitu memperoleh hasil sebesar 89,23\%. Hal ini menunjukkan bahwa media pembelajaran KOPER FK pada materi pencernaan makanan hewan ruminansia dalam kategori "Sangat Valid" Sedangkan hasil hasil validasi media pembelajaran KOPER FK oleh ahli materi yaitu memperoleh hasil sebesar 97,14\%. Hal ini menunjukkan bahwa media pembelajaran KOPER FK pada materi pencernaan makanan hewan ruminansia dalam kategori "Sangat Valid". Dengan demikian media 
pembelajaran KOPER FK materi FPB dan KPK terbukti sangat valid dan telah memenuhi kelayakan dari segi kevalidan dalam proses pembelajaran.

\section{Kepraktisan Media Pembelajaran SPASI}

Kriteria kedua dalam media pembelajaran KOPER FK yaitu praktis. Menurut Nieveen dalam Subekti (2010:77), kepraktisan dapat dilihat dari dua hal, yaitu jika ahli dan praktisi menyatakan bahwa sesuatu yang dikembangkan dapat terapkan dan dalam kenyataannya sesuatu yang dikembangkan itu memang benar-benar dapat diterapkan. Dalam hal ini kepraktisan dalam menggunakan media pembelajaran KOPER FK materi FPB dan KPK dapat diperoleh dengan dua cara, yaitu aktivitas guru dan siswa dalam proses pembelajaran dan angket siswa. Untuk mengetahui mengetahui kepraktisan media pembelajaran KOPER FK materi FPB dan KPKpeneliti menggunakan metode angket yang diberikan kepada peserta didik dan lembar obsever yang diberikan kepada kedua pengamat penelitian.

Dalam kriteria ini, peneliti melakukan dua kali uji coba untuk mengetahui kepraktisan penggunaan media pembelajaran KOPER FK, yaitu uji coba produk skala terbatas dan uji coba pemakaian skala luas. Pada uji coba produk skala terbatas peneliti melakukan uji coba penggunaan media pembelajaran KOPER FK melibatkan 6 peserta didik yang diambil secara acak pada kelas IV SDN Bendan Ngisor Semarang. Sedangkan pada uji coba pemakaian skala luas pengembang melakukan uji coba dengan melibatkan seluruh peserta didik kelas IV SDN Bendan Ngisor Semarang yang berjumlah 40 peserta didik.

Dalam uji coba produk skala terbatas yang berperan sebagai pengajar dalam penelitian ini adalah peneliti. Sebelum proses pembelajaran dimulai peneliti memberikan soal pretest kepada peserta didik untuk mengetahui kemampuan awal peserta didik. Pada saat proses pembelajaran berlangsung, peneliti dan peserta didik menggunakan media pembelajaran KOPER FK materi pencernaan makanan hewan ruminansia. Selanjutnya, peneliti memberikan soal posttest kepada peserta didik untuk mengetahui kemampuan peserta didik dalam menerima materi dan mengetahui nilai hasil belajar peserta didik. Setelah proses pembelajaran selesai, peneliti memberikan angket kepada masing-masing peserta didik untuk mengetahui kepraktisan media pembelajaran KOPER FK dari sudut pandang peserta didik sebagai penerima dan pengguna materi.

Dalam uji coba kedua yaitu uji coba pemakaian skala luas yang berperan sebagai pengajar dalam penelitian ini adalah guru kelas. Sedangkan yang 
berperan sebagai pengamat dalam uji coba pemakaian skala luas ini adalah peneliti dan teman sejawat. Sebelum proses pembelajaran dimulai, guru memberikan soal pretest kepada peserta didik untuk mengetahui kemampuan awal peserta didik. Pada saat proses pembelajaran berlangsung, guru dan peserta didik menggunakan media pembelajaran KOPER FK materi FPB dan KPK. Selanjutnya, peneliti memberikan soal posttest kepada peserta didik untuk mengetahui kemampuan peserta didik dalam menerima materi dan mengetahui nilai hasil belajar peserta didik. Setelah proses pembelajaran selesai, peneliti memberikan angket kepada masing-masing peserta didik untuk mengetahui kepraktisan media pembelajaran KOPER FK dari sudut pandang peserta didik sebagai penerima dan pengguna materi dan guru sebagai pengguna media.

Aspek yang dinilai untuk mengetahui kepraktisan sebuah produk dalam lembar observasi kegiatan pembelajaran yaitu penguasaan materi pembelajaran, pendekatan strategi pembelajaran, pemanfaatan sumber belajar (media), penilaian proses dan hasil belajar. Sedangkan aspek yang dinilai untuk mengetahui kepraktisan sebuah produk dalam lembar angket siswa yaitu bentuk dari sapi dari media pembelajaran KOPER FK materi FPB dan KPK.

Hasil kepraktisan dari observasi kegiatan pembelajaran pada uji coba pemakaian skala luas dengan menggunakan media pembelajaran KOPER FK oleh kedua obsever, yaitu pada obsever pertama memperoleh hasil sebesar $89 \%$ dan pada obsever kedua memperoleh hasil $86 \%$ Sehingga rata-rata keseluruhan mengenai hasil observasi pelaksanaan pembelajaran dengan menggunakan media pembelajaran KOPER FK materi FPB dan KPK dari kedua obsever, yaitu memperoleh hasil sebesar 87,5\%. Hal ini menunjukkan bahwa media pembelajaran KOPER FK pada materi FPB dan KPK dalam kategori "Sangat Baik".

Hasil angket peserta didik pada uji coba pemakaian skala luas dalam menggunakan media pembelajaran KOPER FK materi FPB dan KPK memperoleh hasil sebesar 305 untuk "ya" dan 15 untuk "tidak". Sehingga rata-rata keseluruhan mengenai angket peserta didik dalam menggunakan media pembelajaran KOPER FK materi FPB dan KPK memperoleh hasil sebesar 95.3\%. Hal ini menunjukkan bahwa tingkat kepraktisan penggunaan media pembelajaran KOPER FK dalam tingkat kategori dalam proses pembelajaran. 
Dengan demikian, dapat diketahui bahwa rata-rata keseluruhan mengenai kepraktisan media pembelajaran KOPER FK materi FPB dan KPK pada uji coba skala luas dalam tingkat kategori "Sangat Baik" sebesar 89,4\%. Sehinhga media pembelajaran KOPER FK materi FPB dan KPK terbukti "Sangat Baik"dalam proses pembelajaran dan telah memenuhi kelayakan dari segi kepraktisan dalam proses pembelajaran.

\section{Kefektifan Media Pembelajaran SPASI}

Kriteria ketiga dalam media pembelajaran KOPER FK yaitu efektif. Menurut Arsyad (2013: 217), efektifitas dapat dilihat dari dua aspek, yaitu bukti-bukti empiris mengenai hasil belajar siswa yang dihasilkan oleh sistem intruksional, dan bukti-bukti yang menunjukkan berapa banyak kontribusi media atau media program terhadap keberhasilan dan keefektifan proses instruksional.

Untuk mengetahui keefektifan media pembelajaran KOPER FK materiFPB dan KPK, peneliti menggunakan metode tes untuk mengetahui hasil belajar kognitif peserta didik baik seblelum maupun sesudah menggunakan media pembelajaran KOPER FK. Hal ini sependapat dengan Sudjana (2011:4) bahwa tujuan dari penilaian hasil belajar adalah untuk (1) mendeskripsikan kecakapan hasil belajar para siswa, (2) mengetahui keberhasilan proses pendidikan dan pengajaran di sekolah, dan (3) menentukan tindak lanjut hasil penilaian.

Dalam kriteria ini, peneliti melakukan dua kali uji coba produk untuk mengetahui keefektifan penggunaan media pembelajaran berbasis macromedia flash, yaitu uji coba produk skala terbatas dan uji coba pemakaian skala luas. Pada uji coba produk skala terbatas peneliti melakukan uji coba produk media pembelajaran KOPER FK dengan melibatkan 6 orang peserta didik kelas IV SDN Bendan Ngisor Semarang yang diambil secara acak. Sedangkan pada uji coba pemakaian skala luas, pengembang melibatkan seluruh peserta didik kelas IV SDN Bendan Ngisor Semarang yang berjumlah 40 peserta didik.

Sebelum proses pembelajaran dimulai, peneliti memberikan soal pretest kepada peserta didik untuk mengetahui kemampuan awal peserta didik. Pada saat proses pembelajaran berlangsung, guru dan peserta didik menggunakan media pembelajaran KOPER FK materi FPB dan KPK. Selanjutnya, peneliti memberikan soal posttest kepada peserta didik untuk mengetahui kemampuan peserta didik daam menerima materi dan mengetahui nilai hasil belajar peserta didik. 
Pada uji coba produk skala terbatas, dapat diketahui bahwa nilai rata-rata hasil belajar peserta didik pada uji coba produk skala terbatas untuk nilai pretest peserta didik sebesar 55,6 sedangkan rata-rata posttest peserta didik sebesar 84,5 dan rata-rata nilai tersebut telah mencapai KKM (Kriteria Ketuntasan Minimal) mata pelajaran Matematika yang berlaku yakni 80 . Peningkatan hasil belajar peserta didik ini dapat dilihat dengan dari hasil pretest dan posttest peserta didik.

Pada uji coba pemakaian skala luas, dapat diketahui bahwa nilai rata-rata hasil belajar peserta didik pada uji coba pemakaian skala luas untuk nilai pretest sebesar 59,92 sedangkan rata-rata posttest peserta didik sebesar 83,8 dan rata-rata nilai tersebut telah mencapai KKM (Kriteria Ketuntasan Minimal) mata pelajaran Matematika yang berlaku yakni 80. Peningkatan hasil belajar peserta didik ini dapat dilihat dengan dari hasil pretest dan posttest peserta didik.

Hal ini sesuai dengan pendapat Sones (dalam McCloud, 2008:106) pengaruh menggunakan media pembelajaran KOPER FK dapat meningkatkan kualitas pembelajaran yang dilihat dalam hasil tes belajar siswa. Begitu pula menurut Sadiman (2008:182) tes formatif dimaksudkan untuk mengumpulkan data tentang efektifitas dan efisiensi bahan-bahan pembelajaran. Keefektifan pelaksanaan proses pembelajaran dengan media diukur melalui bukti-bukti hasil belajar siswa yang dihasilkan dalam sistem pembelajaran (Arsyad dalam Musfiqon, 2012:150).

Dengan demikian dapat diketahui bahwa media pembelajaran KOPER FK dikatakan telah memenuhi kelayakan dari segi efektivitas dalam proses pembelajaran karena dengan menggunakan media pembelajaran KOPER FK dalam proses pembelajaran dapat meningkatkan pemahaman peserta didik secara mendalam mengenai materi, mempermudah mengingat materi jangka panjang, dan menemukan fakta-fakta mengenai materi yang abstrak terhadap materi perncernaan makanan pada hewan ruminansia sehingga hasil belajar pun meningkat secara signifikan.

\section{Simpulan}

Berdasarkan dari hasil penelitian dan pembahasan maka dapat disimpulkan bahwa 1) kevalidan media pembelajaran KOPER FK materi FPB dan KPK ditentukan dari hasil penilaian yang diberikan oleh ahli media dan ahli materi. Pada ahli media, kevalidan media sebesar $91,4 \%$ dan pada ahli materi kevalidan media pembelajaran KOPER FK sebesar 87,6\% dalam kategori "Sangat Valid"; 2) kepraktisan media pembelajaran KOPER FK materi FPB 
dan KPK ditentukan dari hasil observasi pelaksanaan pembelajaran dan angket siswa. Kepraktisan penggunaan media pembelajaran KOPER FK untuk obsever pertama sebesar 89\% dan obsever kedua sebesar 86\%. Dan pada angket siswa, kepraktisan penggunaan media pembelajaran berbasis flash untuk "ya" sebesar 305 dan untuk "tidak" sebesar 15 Sehingga rata-rata perolehan hasil keseluruhan 95,3\%. Dengan demikian rata-rata perolehan hasil keseluruhan mengenai kepraktisan penggunaan media SPASI dan angket siswa sebesar 89,4\% dalam tingkat kategori "Sangat Baik" dalam proses pembelajaran.

Keefektifan media pembelajaran KOPER FK materi FPB dan KPK ditentukan dari hasil penilaian tes belajar siswa dari segi kognitif setelah menggunakan media pembelajaran KOPER FK. Nilai rata-rata hasil belajar siswa pada uji coba produk skala terbatas untuk nilai pretest siswa sebesar 55,6 sedangkan rata-rata posttest siswa sebesar 84,5 dan rata-rata nilai tersebut telah mencapai KKM (Kriteria Ketuntasan Minimal) mata pelajaran Matematika yang berlaku yakni 80. Peningkatan hasil belajar siswa ini dapat dilihat sedangkan pada uji coba pemakaian skala luas untuk nilai pretest sebesar 58,9 sedangkan ratarata posttest siswa sebesar 81,1 .

Guru dapat membuat dan mengembangkan media pembelajaran sederhana namun bermakna sesuai dengan karakteristik siswa sehingga kedepannya guru dapat menerapkan pembelajaran yang lebih aktif, kreatif, bermakna dan menyenangkan bagi siswa. Bagi peneliti yang akan mengembangkan media pembelajaran KOPER FK harus dapat menentukan materi yang tepat dan menarik untuk disajikan dalam media pembelajaran dan menjadi acuan penelitian bila ingin menerapkan dengan materi yang berbeda.

a. Penggunaan bahan harus aman dalam penggunaan dalam penunjang proses pembelajaran dikelas.

b. Peneliti harus bijaksana dalam menyikapi kritik dan saran dari ahli materi dan ahli media.

\section{Daftar Pustaka}

Kustandi, Cecep. Bambang Sutjipto. 2011. Media Pembelajaran Manual dan Digital. Bogor: Ghalia Indonesia

Arsyad, Azhar. 2013. Media Pembelajaran. Jakarta: PT Raja Grafindo Persada Indriana, Dina 2011. Ragam Alat Bantu Media Pengajaran. Yogyakarta: Diva Press.

Karso. 2007 Tujuan Pendidikan Matematika di SD. https://eprints.uny.ac.id/9708/2/BAB\%202\%20-\%2008108241126.pdf (diakses 26 Desember 2019). 
Kustandi, Cecep. Bambang Sutjipto. 2011. Media Pembelajaran Manual dan Digital. Bogor: Ghalia Indonesia

Maryani, Ika. 2015. Pendekatan Scientific dalam Pembelajaran di Sekolah Dasar (Teori dan Praktek). Yogykarta: CV. Budi Utama

Roesminingsih, MV dan Hadi Susarno. 2013. Teori dan Praktik Pendidikan. Surabaya: Unesa University Press.

Sudjana, Nana. 2011. Penilaian Hasil Proses Belajar Mengajar. Bandung: PT Indeks

Sugiyono. 2014. Metode Penelitian Kuantitatif Kualitatif Dan RED. Bandung: Alfabeta

Susilana, dan Riyana. 2007. Media Pembelajaran. Bandung: CV. wacana Prima 